\title{
TRAINING KETERAMPILAN SOSIAL PADA PEMBELAJARAN IPS BERFOKUS EFIKASI DIRI SISWA
}

\author{
${ }^{1}$ Tetep \\ ${ }^{2}$ Ade Suherman \\ 1tetep@institutpendidikan.ac.id \\ 2adesuhermana@gmail.com \\ Insitut Pendidikan Indonesia
}

\begin{abstract}
The social skills training model can improve the self-efficacy of students at Junior High Schools 1, 2 and 3 in Ciamis Region. The training model used is through; (a) modeling system, done by showing examples of specific behavioral skills, $(b)$ role playing, done by listening to instructions presented by the model or via video, (c) feedback on appropriate performance, which is done by giving reinforcer of the participant who demonstrated the right performance. After doing this training model can 1) increase proficiency in social skills; 2) students actively ask the teacher when there are subjects that are not understood, understand and regulate emotions themselves and others (emotional control), 3) students respond to others and direct social action (social attitudes), 4) students interact and communicate verbal and non-verbal (communication) with individuals and other groups so that students become skilled at interacting with people around them, both in formal and informal relationships, 5) students are responsible for their actions (responsibility) and, 6) students pay more attention other people (care).
\end{abstract}

Keywords: Social Skills Trainning, Social Studies Learning, Self Efficacy.

\begin{abstract}
Abstrak
Model training keterampilan sosial dapat meningkatkan efikasi diri siswa di SMP Negeri 1, SMP Negeri 2 dan SMP Negeri 3 Ciamis. Model training yang digunakan melalui; (a) sistem modelling, dilakukan dengan cara memperlihatkan contoh tentang ketrampilan berperilaku yang spesifik, (b) bermain peran, dilakukan dengan cara mendengarkan petunjuk yang disajikan model atau melalui video, (c) umpan balik terhadap kinerja yang tepat, yang dilakukan dengan cara memberi pengukuh terhadap peserta yang menunjukkan kinerja yang tepat. Setelah dilakukannya model training ini dapat 1)meningkatnya kecakapan dalam keterampilan sosial; 2) siswa aktif bertanya kepada guru ketika ada mata pelajaran yang tidak dimengerti, memahami dan mengatur emosi diri maupun orang lain (kontrol emosi), 3) siswa merespon orang lain dan mengarahkan tindakan sosial (sikap sosial), 4) interaksi dan berkomunikasi siswa secara verbal maupun non verbal (komunikasi) dengan individu dan kelompok lainnya sehingga membentuk siswa menjadi trampil berinteraksi dengan orang-orang di sekitarnya, baik dalam hubungan formal maupun informal, 5) siswa bertanggung jawab atas tindakan (tanggung jawab) dan, 6) siswa lebih memperhatikan orang lain (peduli).
\end{abstract}

Kata kunci: Training Keterampilan Sosial, Pembelajaran IPS, Efikasi Diri 


\section{PENDAHULUAN}

Keterampilan sosial siswa merupakan modal penting dalam bersosialisasi dan beradaftasi bagi lingkungannya, seperti lingkungan sekolah, keluarga dan masyarakat. Keterampilan sosial dibutuhkan bagi individu yang terus berkembang untuk mengatasi berbagai konflik yang terjadi di masyarakat serta belajar dari kenyataan dan sistuasi seperti kehidupan sebenarnya. Pengetahuan, pemahaman, dan keterampilan dalam menjalani hubungan sosial menjadi sebuah keharusan bagi seseorang. Mengembangkan keterampilan sosial dalam mata pelajaran IPS di Sekolah Menengah Pertama (SMP) oleh seorang guru atau pendidik bukan saja untuk mengajarkan materi pelajaran saja, melainkan dituntut untuk menjadi guru yang mempunyai kemampuan untuk mengembangkan, mencontohkan, dan melatih para siswanya untuk mempunyai keterampilan sosial dalam pembelajarannya. Namun pada kenyataannya, kondisi ideal selalu bersebrangan dengan kenyataan. Para guru belum mampu mengembangkan keterampilan sosial dalam pembelajaran IPS pada siswanya.

Mujiatin Setyana (2014) "pemahaman guru tentang keterampilan sosial kurang; RPP belum mengarah pada pengembangan keterampilan sosial, model cooperative learning yang digunakan dalam pembelajaran belum maksimal; penilaian yang dilakukan oleh guru IPS cenderung kognitif, sedangkan penilaian afektif dan psikomotor diabaikan".

Keterampilan sosial merupakan hal yang sangat penting dalam bersosialisasi dan berinteraksi antar sesama manusia, baik dalam hal berkomunikasi maupun bertingkah laku dengan orang lain. Hal ini juga sesuai dengan pendapat dari Cartledge dan Milbum (dalam Maryani, 2011:17) yang menyatakan bahwa: "keterampilan sosial merupakan perilaku yang dapat dipelajari, karena memungkinkan individu dapat berinteraksi, mempengaruhi respon positif dan negatif. Keterampilan ini sangat dibutuhkan di kehidupan yang akan datang dalam menjalani hubungan sosial di masyarakat". Tallat Rashid (2010) "keterampilan sosial belum berkembang di kalangan anak-anak sejauh yang diharapkan. Namun, siswa telah belajar untuk menunjukkan rasa hormat terhadap orang lain lebih dari toleransi keterampilan sosial lainnya dari perbedaan individu. Ditemukan bahwa variabel latar belakang seperti jenis kelamin, lokal dan kelas adalah sumber perbedaan dalam pengembangan keterampilan sosial.

Kurikulum pendidikan SMP cenderung lebih menekankan pada kemampuan akademik sebagai tujuan pembelajaran, dibandingkan aspek lainnya. Pada masa SMP, anak dihadapkan pada berbagai keadaaan yang cenderung berbeda dari sebelumnya. Remaja dihadapkan pada lingkungan fisik, individu-individu dan aturan baru, oleh karenanya diperlukan keterampilan-keterampilan yang mampu membuat remaja bertahan dan diterima.

Seema, G. B., Kumar, G. Venkatesh (2018) "masa remaja adalah masa pertumbuhan, tantangan dan perubahan. Dalam konteks saat ini, remaja memiliki dunianya sendiri di mana hubungan sosial membentuk perkembangan masa depan mereka. Seorang remaja sedang dalam tahap booming dalam menjalin hubungan. Karena itu, pentingnya keterampilan sosial dalam masa remaja sangat krusial. Hubungan sosial yang baik adalah faktor utama dalam kesejahteraan sosial dan 
perkembangan remaja positif yang membantu dalam membentuk masa depan individu".

Mohd Taib Harun (2017) menjelaskan bahwa "program luar ruangan memiliki pengaruh yang signifikan untuk semua konstruksi yang terlibat dalam penelitian ini. Cohen $\mathrm{D}$ menunjukkan bahwa perawatan berkontribusi besar terhadap kemampuan kepemimpinan (60\%), dan kemampuan untuk mengatasi perubahan $(61 \%)$. Wilks 'Lambda dalam berbagai analisis varians menunjukkan bahwa modul pendidikan luar ruangan memberikan kontribusi yang sangat tinggi $\mathrm{F}$ $=30,78, \mathrm{p}<0,05 ;{ }^{\prime} \mathrm{H} 2=0,57$ untuk perubahan keterampilan sosial".

Analisis varian menunjukkan bahwa ada periode retensi di mana perubahan dalam keterampilan sosial yang diteliti tetap berada di dalam partisipan selama periode waktu tertentu. Retensi perubahan dalam keterampilan sosial ini penting untuk semua faktor yang dipelajari, yaitu kerja tim yang kooperatif, kemampuan kepemimpinan, dan kemampuan untuk mengatasi perubahan.

Setiap perubahan pada siswa merupakan situasi dimana siswa mengalami proses pematangan perkembangan. Tugas guru IPS khususnya dalam mengoptimalkan proses perkembangan menggali potensi-potesi dan kondisi yang ada pada diri siswa. Pandangan Supriatna (2007) bahwa "kondisi pembelajaran IPS masih cenderung pada kurikulum yang berorientasi penguasaan materi subjek (esensialisme) sehingga belum mampu mengembangkan keterampilan sosial siswa secara maksimal". Paradigma esensialisme lebih menekankan pada transfer of knowledge sehingga mengabaikan aspek afektif siswa. Pembelajaran IPS dengan menggunakan paradigma ini memposisikan guru sebagai pusat belajar dan siswa sebagai objek yang pasif. Kondisi tersebut memberikan waktu yang lebih banyak kepada guru untuk memberikan materi IPS secara maksimal sehingga banyak sekali aspek sosial yang ditinggalkan.

Mohammad Shakeri1, at.all. (2015) Hasil penelitian menunjukkan bahwa ada perbedaan yang signifikan antara kedua kelompok berdasarkan skor Assertiveness ( $p$-value $<0 / 001$ ). Namun, ada perbedaan signifikan yang ditemukan pada skor Self-efficacy Akademik antara kedua kelompok. Pelatihan keterampilan sosial dapat secara signifikan meningkatkan aspek-aspek Ketegasan Diri pada Siswa dengan disleksia.

Pelatihan ini dapat dilakukan dengan cara bermain peran, menirukan model yang diperankan video, menirukan model yang diperankan teman sebaya, dan setting in-vivo (Bulkeley dan Cramer, 1990). Beberapa teknik yang digunakan dalam pelatihan ketrampilan sosial adalah:

(1) Modelling, yang dilakukan dengan cara memperlihatkan contoh tentang ketrampilan berperilaku yang spesifik, yang diharapkan dapat dipelajari oleh pelatih.

(2) Bermain Peran, dilakukan dengan cara mendengarkan petunjuk yang disajikan model atau melalui video. Setelah itu biasanya dilanjutkan dengan diskusi mengenai aktivitas yang dimodelkan

(3) Umpan Balik terhadap Kinerja yang Tepat, yang dilakukan dengan cara memberi pengukuh terhadap peserta yang menunjukkan kinerja yang tepat, apabila peserta berhasil melakukan peran yang dilatihkan secara in-vivo, maupun apabila peserta mengemukakan target perilaku yang ingin dilakukan. 
Menurut Sikula (As'ad, 2003), training merupakan proses pendidikan jangka pendek yang mempergunakan prosedur yang sistematis dan terorganisir, guna mempelajari pengetahuan dan ketrampilan teknis untuk tujuantujuan tertentu.

Fakta dilapangan bahwa keterampilan sosial siswa dalam pembelajaran IPS masih tergolong rendah. Pertama, di dalam kelas siswa masih terlihat berkelompok-kelompok. Mereka belum mampu berbaur dengan teman sekelasnya. Kedua, siswa belum mampu menunjukkan sikap dan bahasa yang sopan terhadap guru dan temannya. Hal tersebut terlihat ketika guru dan siswa sedang melakukan tanya jawab di kelas. Siswa cenderung menjawab pertanyaan guru dengan asalasalan dan tidak menggunakan bahasa yang sopan santun. Ketiga, ketika menjawab pertanyaan guru, siswa hanya membacakan informasi yang ada di buku paket saja tanpa menyaringnya terlebih dahulu. Hal ini dapat dikatakan bahwa siswa belum mampu mengolah dan menggunakan sumber informasi yang didapat.

Banyak faktor yang menyebabkan kurangnya keterampilan sosial siswa dalam pembelajaran IPS. Sukardi (Wiyanarti, 2008: 135)menjelaskan bahwa ketidak mampuan guru IPS mengembangkan keterampilan sosial siswa disebabkan oleh "jarang guru IPS yang mampu mencari kaitan antar materi IPS". Di samping itu, menurut Gresham, dkk (Kaser, 2009: 1) bahwa "There are various reasons why students may not perform appropriate social skills; they do not know a skill or because they do not know how or when to use it". Pendapatnya dapat diartikan bahwa ada berbagai alasan mengapa siswa tidak menunjukan keterampilan sosialnya; mereka tidak mengetahui kemampuannya atau mereka tidak mengetahui bagaimana dan kapan menggunakannya. Jadi, jika dilihat dari pendapat tersebut kurangnya keterampilan sosial pada siswa bukan hanya ketidakmampuan guru untuk mengembangkannya, tetapi jika siswa tidak menggali keterampilannya maka keterampilan sosialnya pun tidak akan berkembang.

Berdasarkan penelitian Sharon M. Kolb (2011) Pengembangan self efficacy harus menjadi bidang perhatian utama dalam perencanaan pendidikan kami untuk semua siswa. Self efficacy memainkan peran penting dalam pengembangan keterampilan sosial seperti motivasi, kesadaran diri, Pemodelan dan pembelajaran observasional adalah faktor yang mendukung pengembangan self efficacy. Ini naskah akan memeriksa peran self efficacy dalam pengembangan keterampilan sosial dan faktor penghambat pengembangan kemanjuran pada anak-anak. Menurut Ormrod (2008: 20) secara umum efikasi diri (self efficac) adalah penilaian seseorang tentang kemampuannya sendiri untuk menjalankan perilaku tertentu atau mencapai tujuan tertentu. Dengan kata lain efikasi diri dapat diartikan keyakinan bahwa seseorang mampu menjalankan perilaku tertentu atau tujuan tertentu. Menurut Bandura dalam Ormrod (2008:21) perasaan self-efficacy siswa memengaruhi pilihan aktivitas mereka, tujuan mereka, dan usaha serta persistensi mereka dalam aktivitas-aktivitas kelas. Dengan demikian self-efficacy pun pada akhirnya mempengaruhi pembelajaran dan prestasi mereka. Penelitian Tetep \& A. Suparman (2019) menjelaskan bahwa media literacy and social character are two attached entities closely related to individual competence because it is related to personality, character, and noble character.

Faktor-faktor yang mempengaruhi self efficacy menurut Ormrod (2008:23) diantarnya adalah keberhasilan dan kegagalan pembelajar sebelumnya, pesan yang 
disampaikan orang lain, keberhasilan dan kegagalan orang lain, dan keberhasilan dan kegagalan dalam kelompok yang lebih besar. Menurut Huda (2013:61) untuk meningkatkan efikasi diri yang harus dilakukan oleh guru adalah mengembangkan lingkungan belajar dimana semua siswa dapat mengembangkan kemajuan diri dan motivasinya untuk beraktivitas. Guru perlu menciptakan lingkungan yang memungkinkan para siswa untuk menguasai materinya, memberi kekayaan akademik kepada siswa yang berbakat, serta memberi perhatian dan dukungan terhadap mereka yang kesulitan secara akademik. Penelitian Mohd Zulfabli Hasan (2014) ditemukan bahwa ada hubungan yang signifikan antara self-efficacy dan kinerja akademik. Selain itu, faktor-faktor seperti penguasaan pengalaman, pengalaman perwakilan, bujukan verbal dan gairah psikologi benar-benar mempengaruhi self-efficacy.

Menurut Huda (2013:61) untuk meningkatkan efikasi diri yang harus dilakukan oleh guru adalah mengembangkan lingkungan belajar dimana semua siswa dapat mengembangkan kemajuan diri dan motivasinya untuk beraktivitas. Guru perlu menciptakan lingkungan yang memungkinkan para siswa untuk menguasai materinya, memberi kekayaan akademik kepada siswa yang berbakat, serta memberi perhatian dan dukungan terhadap mereka yang kesulitan secara akademik. Menurut Bandura (1977) pengukuran Self efficacy yang mengacu pada tiga dimensi. Pengukuran Self efficacy dapat dilakukan melalui salah satu dimensi atau kombinasi antara dimensi magnitude, Generalilty dan Streght. Adapun dimensi Self efficacy sebagai berikut: $a$. Magnitude Menunjukkan kepada tingkat kesulitan yang diyakini oleh individu untuk dapat diselesaikan. $b$. Streght Menunjukan kepada kuat atau lemahnya keyakinan individu terhadap kesulitan tugas yang dikerjakan. Self efficacy yang lemah mudah ditiadakan oleh pengalaman yang sulit. Sebaliknya orang yang memiliki keyakinan yang kuat dalam kompetensi akan mempertahankan usaha meskipun mangalami kesulitan. c. Generalilty Menunjukkan apakah keyakinan akan berlangsung dalam dominasi tertentu atau berlaku dalam berbagi aktifitas. Maka dapat disimpulkan self-efficacy atau efikasi diri merupakan keyakinan diri siswa yang berpengaruh terhadap keberhasilan proses kognitif dan motivasi yang berlangsung dalam pembelajaran dimana guru menjadi fasilitator yang berperan dalam mengembangkan lingkungan belajar untuk keyakinan diri siswa itu sendiri.

\section{KAJIAN TEORITIS}

Dalam pembelajaran IPS, keterampilan social merupakan bagian dari tujuan pembelajaran IPS itu sendiri atau sebagai body of knowledge, sehingga memberikan penegasan bahwa pembelajaran IPS bertujuan pada pengembangan kapasitas manusia sebagai makhluk social. Aspek pembelajaran IPS meliputi aspek taksonomi yang dijelaskan oleh Bloom yang terdiri dari Kognitif, Afektif dan Psikomotorik. Seperti dijelaskan Mulyono (1985:15) aspek keterampilan yang harus diajarkan melalui pembelajaran IPS adalah "keterampilan berfikir, keterampilan akademis, keterampilan sosial, dan keterampilan menelit". Berkaitan dengan keterampilan sosial, maka tujuan pengembangan keterampilan sosial dalam mata pelajaran IPS adalah agar siswa mampu berinteraksi dengan teman- temanya 
sehinga mampu menyelesaikan tugas bersama, dan hasil yang dicapai akan dirasakan kebaikanya oleh semua angota masing-masing.

Menurut Merel (208) bahwa keterampilan sosial (Social Skil) sebagai perilaku spesifk, inisiatif, mengarahkan pada hasil sosial yang diharapkan sebagai bentuk perilaku seseorang. Sementara Combs \& Slaby (Gimpel dan Merel, 198) menjelaskan bahwa keterampilan sosial (Social Skil) adalah kemampuan berinteraksi dengan orang lain dalam konteks sosial dengan cara-cara yang khusus yang dapat diterima secara social maupun nilai-nilai dan disat yang sama berguna bagi dirnya dan orang lain.

Sekolah sebagai Lembaga social atau wahana social merupakan tempat siswa bagaimana mengembangkan keterampilan sosialnya sehingga memiliki peranan yang sangat penting dalam mengembangkan keterampilan social yang dimiliki oleh siswanya.

Salah satu dimensi yang ada dalam keterampilan social itu adalah Efikasi diri. Secara teoritis bahwa efikasi diri merupakan bagian dari teori social cognitive dari Albert Bandura (1994) yang menurutnya menekankan pada peran belajar observasional, pengalaman social dan determinisme timbal balik dalam pengembangan kepribadian. Seperti dijelaskan dalam Feist \& Feist (2010:212) bahwa self efficacy adalah keyakinan seseorang dalam kemampuanya untuk melakukan suatu bentuk control terhadap kemampuan orang itu sendiri dan kejadian dalam lingkunganya.

Efikasi diri merupakan salah satu aspek pengetahuan tentang diri (self knowledge) hal ini dapat mempengaruhi seorang individu dalam mengambil keputusan. Menurut Santrock (2007:286) bahwa Efikasi diri sangat berpengaruh besar terhadap perilaku seseorang. Menurut Alwisol (2009) bahwa efikasi diri merupakan persepsi didi sendiri mengenai seberapa bagus dapat berfungsi dalam situasi tertentu dalam pandangan bahwa diri dapat melakukan Tindakan sesuai dengan yang diharapkan. Dengan demikian bahwa efikasi diri menjadi bumbu dari berkembangnya keterampilan social seseorang baik dalam dirinya maupun lingkunganya. Pembentukan ketrampilan social memiliki peran besar dalam efikasi dirinya sendiri.

\section{METODE PENELITIAN}

Salah satu jenis penelitian kualitatif deskriptif eksploratif adalah berupa penelitian dengan metode atau pendekatan studi kasus (Case Study). Data studi kasus dapat diperoleh dari semua pihak yang bersangkutan, dengan kata lain data dalam studi ini dikumpulkan dari berbagai sumber (Nawawi, 2003). Sebagai sebuah studi kasus maka data yang dikumpulkan berasal dari berbagai sumber dan hasil penelitian ini hanya berlaku pada kasus yang diselidiki. Lebih lanjut Arikunto (1986) mengemukakan bahwa metode studi kasus sebagai salah satu jenis pendekatan deskriptif, adalah penelitian yang dilakukan secara intensif, terperinci dan mendalam terhadap suatu organisme (individu), lembaga atau gejala tertentu dengan daerah atau subjek yang sempit. Penelitian case study atau penelitian lapangan (field study) dimaksudkan untuk mempelajari secara intensif tentang latar belakang masalah keadaan dan posisi suatu peristiwa yang sedang berlangsung saat ini, serta interaksi lingkungan unit sosial tertentu yang bersifat apa adanya (given). Subjek penelitian dapat berupa individu, kelompok, institusi atau masyarakat. 
Penelitian case study merupakan studi mendalam mengenai unit sosial tertentu dan hasil penelitian tersebut memberikan gambaran luas serta mendalam mengenai unit sosial tertentu. Subjek yang diteliti relatif terbatas, namun variabel-variabel dan fokus yang diteliti sangat luas dimensinya (Danim, 2002 ).

\section{HASIL DAN PEMBAHASAN}

Berdasarkan hasil penelitian di SMPN 1, SMPN 2 dan SMPN 3 Ciamis, dinyatakan bahwa; Training (pelatihan) ketrampilan sosial yang dilakukan di SMP Negeri 1 Ciamis merupakan metode atau teknik modifikasi perilaku, terutama dapat membantu siswa penderita kesulitan bergaul. Teknik ini dapat digunakan sebagai teknik tunggal maupun teknik pelengkap yang digunakan bersama-sama dengan teknik psikoterapi lainnya. 2) Keterampilan yang dilakukan guru IPS sangat beragam, upaya tersebut dimulai dari penjelasan terkait pentingnya mempunyai keterampilan dalam diri sendiri, cara menumbuhkan dan meningkatkan keterampilan sosial, dan manfaat memiliki keterampilan sosial. Guru IPS tidak hanya menerangkan tentang teori, tetapi juga mengaplikasikan dalam kehidupan bemsyarakat. 3) Guru mata pelajaran IPS, dituntut untuk melakukan perubahan, baik dalam segi cara pemikiran maupun tingkah laku siswa untuk menanamkan dan menumbuh kembangkan keterampilan sosial dalam diri siswa. 4) Guru memberikan bantuan dan bimbingan kepada siswa yang belum bisa meningkatkan keterampilan sosial dalam dirinya sendiri, 5) kurikulum yang digunakan di SMP Negeri 1 Ciamis yaitu K-13, dimana kutikulum tersebut bertujuan untuk pembinaan karakter siswa. Sehingga dengan begitu, pendekatan individual yang dilaksanakan guru IPS untuk meningkatkan keterampilan sosial siswa, lebih mudah untuk diterapkan, 6) Pelaksanaan proses pembelajaran mata pelajaran IPS dilakukan dengan menitikberatkan pada perubahan dan pembentukan karakter individu dan sosial siswa sehingga dapat dilaskanakan yang jauh lebih baik dari sebelumnya.7) Keterampilan sosial yang dimiliki siswa brtujuan untuk bersosial baik dilingkungan sekolah maupun dengan masyarakat. Hal tersebut berdampak pada pengakuan dan disegani dimasyarakat manakala siswa tersebut memiliki kemampuan dalam dirinya. Kemampuan dalam diri tersebut menandakan keberhasilan dalam proses pendidikan, tidak hanya diukur dari tingkat inteligensinya saja tetapi juga perubahan dalam tingkah laku dan praktik dalam kehidupan nyata, mengenai apa yang sudah dapatkan selama proses pembelajaran. 8) Keterampilan sosial individu siswa mampu menyesuaikan diri dengan lingkungan sosialnya, mengembangkan kepribadian dan identitas, mengembangkan kemampuan karir, meningkatkan kualitas hidup, meningkatkan kesehatan, serta mampu mengatasi stres.

\section{KESIMPULAN}

Berdasarkan temuan dilapangan setelah dilakukannya training keterampilan sosial dapat meningkatkan efikasi diri siswa di SMP Negeri 1, SMPN 2, dan SMPN 3 Ciamis, hal tersebut dilihat dari; siswa yang sudah melakukan tarining terlihat cakap dalam keterampilan sosial, seperti memberanikan diri untuk bertanya kepada guru ketika ada mata pelajaran yang tidak dimengerti, memahami dan mengatur emosi diri maupun orang lain (kontrol emosi), merespon orang lain dan mengarahkan tindakan sosial (sikap sosial), interaksi dan berkomunikasi secara 
verbal maupun non verbal (komunikasi), bertanggung jawab atas tindakan (tanggung jawab), dan memperhatikan orang lain (peduli). Dapat mengatasi tingkat kesulitan siswa dalam bergaul atau bersosialisasi, mulai dari kesulitan bergaul situasional atau bergaul di situasi-situasi tertentu saja, sampai ke tingkat kesulitan bergaul yang disebabkan oleh gangguan mental kronik. Pelatihan keterampilan sosial dapat mengajarkan kemampuan berinteraksi siswa dengan individu dan kelompok lainnya sehingga membentuk siswa menjadi trampil berinteraksi dengan orang-orang di sekitarnya, baik dalam hubungan formal maupun informal.

\section{REFERENSI}

[1]. Alwisol. 2009. Psikologi Kepribadian edisi revisi. Malang : UMM Press

[2]. Arikunto, Suharsimi. 1986. Prosedur Peelitian Suatu Pendekatan Praktek. Jakarta: Bina Aksara.

[3]. As'ad, M. (2003). Seri ilmu sumber daya manusia: Psikologi industri. Yogyakarta: Liberty.

[4]. Bandura, Albert. 1994. Social Learning Theory. Prentice-Hall, Inc., New Jersey.

[5]. Bulkeley, R. and Cramer, D.., 1990, Social Skills Training with Young Adolescent, Journal of Youth and Adolescence, 19, (5), 451-463.

[6]. Danim, Sudarwan. 2002. Menjadi Peneliti Kualitatif, Bandung: Pustaka Setia.

[7]. Elliot \& F.M. Gresham (eds), 2009. Handbook of Behavior Therapy in Education. New York : Pleum. Mofrad, S., \& Herbert, M.

[8]. Feist, J. \& Gregory J. Feist. (2010). Teori Kepribadian (Edisi ketujuh). Jakarta: Penerbit Salemba Humanika.

[9]. Gimpel, G. A., \& Merrel, K. W. 1998 .Social Skills of Children and Adolescents : Conceptualization, Assessment, Treatment. Mahwah, NJ : Erlbaum

[10]. Hadari, Nawawi. , 2003. Metode Penelitian Bidang Sosial, Gajah Mada University Press, Yogyakarta.

[11]. Huda, Miftahul. 2013. Model-Model PengajarandanPembelajaran. Yogyakarta:PustakaPelajar.

[12]. John W. Santrock (2007). Perkembangan Anak. Jilid 1 Edisi kesebelas. Jakarta : PT. Erlangga.

[13]. Merrell, K. W. (2008). Helping students overcome depression and anxiety: A practical guide (2nd ed.). New York, NY: Guilford.

[14]. Maryani, Enok. 2009. Pengembangan Program Pembelajaran IPS Untuk Peningkatan Keterampilan Sosial. Vol. 9. No.1.

[15]. Mohammad Shakeri1, at.all. (2015). Assertiveness and Academic SelfEfficacy of Dyslexic Students. International Journal of Academic Research in Psychology January 2015, Vol. 2, No. 1 ISSN 2312-1882, http://dx.doi.org/10.6007/IJARP/v2-i1/1664.

[16]. Mohd Taib Harun. 2017. Promoting Social Skills through Outdoor Education and Assessing Its' Effects. (Asian Social Science; Vol. 10, No. 5; 2014 ISSN 1911-2017 E-ISSN 1911-2025, Published by Canadian Center of Science and 
Education, URL: http://dx.doi.org/10.5539/ass.v10n5p71 , diakses 30 Oktober 2019, Pkl. 09.30 WIB.

[17]. Mohd Zulfabli Bin Hasan, 2Md. Tareq Bin Hossain and $3 \mathrm{Md}$. Aminul Islam 2014. Factors Affecting Self-Efficacy Towards Academic Performance: A Study on. Polytechnic Students in Malaysi . AENSI Journals Advances in Environmental Biology ISSN-1995-0756 EISSN-1998-1066. Journal home page: http://www.aensiweb.com/aeb.html . Diakses 30 Oktober 2019, pukul 14.00 WIB.

[18]. Mulyono. (1985). Pengertian dan Karakterisitk IPS. Jakarta : P3G Depdikbud.

[19]. Mujiatin Setyana. 2014. Peran Guru dalam Mengembangkan Keterampilan Sosial Siswa Mata Pelajaran IPS di SMK, http://journal.um.ac.id/index.php/jph, Jurnal Pendidikan Humaniora, Vol. 2 No. 1, Hal 84-88, Maret 2014, ISSN: 2338-8110, Diakses 30 Oktober 2019, pkl 09.00WIB.

[20]. Nana Supriatna, 2007. Bahan belajar Mandiri Pendidikan IPS di SD. Bandung:UPI Pers.

[21]. Ormord, Jeanne ellis. 2008. Psikologi Pendidikan Jilid I. Jakarta:Erlangga.

[22]. Santrock, J. W. (2009). Psikologi Pendidikan. Edisi 3. Buku 2. Alih bahasa Diana Angelica. Jakarta: Salemba Humanika.

[23]. Seema, G. B., Kumar, G. Venkatesh . 2018. Impact of Social Skills Training on Self-Esteem among Male and Female Adolescent Students, Indian Journal of Positive Psychology. https://www.questia.com/read/1P42030130801/impact-of-social-skills-training-on-self-esteem-among, Diakses 30 Oktober 2019, pkl 10.00 WIB.

[24]. Sharon M. Kolb (2011). Self-Efficacay: A Necessary Social Skills Curricula Component. Journal of Emerging Trends in Educational Research and Policy Studies (Jeteraps) 2(4):206-210 (ISSN:2141-6990) Journal of Emerging Trends in Educational Research and Policy Studies (Jeteraps) 2(4):206-210 (ISSN:2141-6990).

[25]. Sukardi, Wayanti. (2008). Sejarah Sebuah Penilaian . Bandung : Jurusan Pendidikan Sejarah FPIPS. UPI Bandung.

[26]. Tallat Rashid. 2010. Development of Social Skills among Children at Elementary Level. Bulletin of Education and Research. June 2010, Vol. 32, No. 1 pp 69-78, https://www.researchgate.net, publication, 234626629_The_Central_Role, diakses 30 oktober 2019, Pkl 09.00 WIB.

[27]. Tetep; Asep Suparman. (2019) Students' Digital Media Literacy: Effects on Social Character. International Journal of Recent Technology and Engineering (IJRTE). Blue Eyes Intelligence Engineering \& Sciences Publication. ISSN: 2277-3878, Volume-8 Issue-2S9, September 2019. 